\title{
MODUL PENDIDIKAN PERLINDUNGAN ANAK DARI KEKERASAN SEKSUAL UNTUK GURU SEKOLAH DASAR
}

\author{
Novi Trilisiana, Christina Ismaniati, Dian Wahyuningsih \\ Teknologi Pendidikan, Universitas Negeri Yogyakarta \\ novitri@uny.ac.id, christina_ismaniati@uny.ac.id,dianw@uny.ac.id
}

\begin{abstract}
Abstrak
Modul bagi guru dapat dijadikan sebagai sumber belajar yang digunakan secara mandiri dan fleksibel, sehingga guru dapat mengembangkan kompetensi mendidik siswa agar terhindar dari kekerasan seksual. Penelitian ini bertujuan untuk menghasilkan produk pengembangan berupa modul pendidikan perlindungan anak dari kekerasan seksual untuk guru sekolah dasar. Penelitian ini dilaksanakan melalui model penelitian prosedural yang mengacu pada model desain instruksional Dick dan Carey. Model ini memiliki sepuluh langkah: mengidentifikasi tujuan pembelajaran umum, melakukan analisis instruksional, menganalisis karakteristik awal pengguna dan konteks instruksional, merumuskan tujuan instruksional khusus, mengembangkan instrumen penilaian hasil belajar, mengembangkan strategi pembelajaran, mengembangkan bahan ajar, melakukan evaluasi formatif, dan melakukan revisi. Modul yang dihasilkan telah dinyatakan layak dalam kategori sangat baik. Produk ini disimpulkan layak untuk digunakan berdasarkan penilaian aspek desain pembelajaran, konten modul, dan media.
\end{abstract}

Kata Kunci: Modul guru; Anti kekerasan seksual anak; Pendidikan seksual

\section{CHILD PROTECTION EDUCATION MODULE FROM SEXUAL VIOLENCE FOR ELEMENTARY SCHOOL TEACHERS}

\begin{abstract}
The module for teachers can be used as a learning resource that is used independently and flexibly, so that teachers can develop competencies in educating students to avoid sexual violence. This study aims to produce a development product in the form of a child protection education module from sexual violence for elementary school teachers. This research was conducted through a procedural research model that refers to the Dick and Carey instructional design model. This model has ten steps: identifying general learning objectives, conducting instructional analysis, analyzing the user's initial characteristics and instructional context, formulating specific instructional goals, developing learning outcome assessment instruments, developing learning strategies, developing teaching materials, conducting formative evaluations, and making revisions. The resulting module has been declared feasible in the very good category. It is concluded that this product is suitable for use based on the assessment of aspects of learning design, module content, and media
\end{abstract}

Keywords: Module for teachers; Anti child sexual violence; Sexual education.

\section{PENDAHULUAN}

Permasalahan tentang kekerasan seksual pada anak menjadi tugas bersama, tidak hanya orang tua tetapi juga guru dan lingkungan sekitar. Upaya perlindungan anak dari kekerasan secara umum (termasuk di dalamnya kekerasan seksual) telah dijabarkan oleh Gani (2018) melalui kebijakan pemerintah yang berbentuk undang-undang maupun peraturan pemerintah, membangun hubungan yang baik antara orang tua dengan anak, membangun sensitivitas anak pada niat jahat orang lain, memastikan jalur yang dilalui anak adalah aman, memberikan kontak yang perlu dihubungi jika keadaan darurat, dan mengajarkan anak mengenal dan melindungi bagian tubuh yang sensitif.

Meskipun anak-anak usia sekolah dasar termasuk rentan menjadi korban kekerasan seksual, mereka telah mampu mendapatkan edukasi agar tidak menjadi korban. Proses edukasi tentu harus disesuaikan dengan perkembangan dan karakteristik siswa sekolah dasar (mulai dari kelas bawah sampai kelas atas). Upaya terdahulu dilakukan oleh Sitanggan dan Sumaryanto (2018) dalam rangka mencegah kejahatan seksual pada anak usia dini melalui pendidikan seks (meliputi menonton film pendek, mengamati gambar poster, dan bermain peran) yang menghasilkan peningkatan pemahaman anak dalam melindungi diri. Hal ini menunjukkan bahwa 
upaya pembelajaran dapat dilakukan sedini mungkin dan disesuaikan dengan berbagai strategi yang dapat diadaptasi oleh guru.

Guru memiliki posisi strategis dalam mengedukasi siswa karena guru dibekali kompetensi pedagogik yang merupakan kemampuan pemahaman terhadap peserta didik, perancangan dan pelaksanaan pembelajaran, evaluasi hasil belajar, dan pengembangan peserta didik untuk mengaktualisasikan berbagai potensi yang dimilikinya (Supardi 2013). Termasuk di dalamnya adalah melatih siswa berpikir kritis untuk mengenal sinyal kekerasan seksual sehingga mereka sadar atas ancaman menjadi korban kekerasan seksual.

Kekerasan seksual terhadap anak merupakan eksploitasi anak untuk kepuasan seksual orang dewasa (Kinnear, 2007). Kekerasan ini melibatkan bujukan atau paksaan kepada anak untuk ambil bagian dalam kegiatan seksual, atau mendorong anak untuk berperilaku dalam kegiatan seksual yang tidak pantas, termasuk di dalamnya memaksa anak untuk berinteraksi seksual kontak dan non-kontak dengan orang dewasa (Suyanto, 2010). UNICEF menjabarkan lebih luas bentuk kekerasan seksual pada anak yang meliputi pelecehan seksual, penganiayaan, inses, perkosaan, usaha perkosaan, pemaksaan seks oral, sentuhan yang tidak pantas, dan pernikahan paksa.

Anak-anak rentan mengalami kekerasan seksual karena karakteristik anak yang lemah dan masih tunduk pada otoritas orang dewasa (Fathiyah, 2010; Hikmah, 2017). Anak belum memiliki pengetahuan yang memadai mengenai perilaku seksual dan ditambah lagi lingkungan yang tidak aman menyebabkan kekerasan seksual terjadi pada anak. Secara tidak langsung, anak belum mengetahui bahwa hak anak telah direnggut.

Efianingrum (2010) merekomendasikan untuk mempromosikan hak anak di sekolah dalam rangka mencegah kekerasan. UNICEF dalam Cowie \& Jennifer (2009) menyatakan bahwa salah satu ukuran pencapaian sebuah bangsa adalah seberapa baik negara memelihara anak-anak dari segi kesehatan, keselamatan, kesejahteraan, pendidikan, perasaan ingin dikasihi, dihargai dalam perannya di keluarga dan masyarakat.

Anak yang menjadi korban dari kekerasan seksual pun dilindungi hukum pada peraturan perundang-undangan khususnya Undang-Undang Nomor 11 Tahun 2012 Tentang Sistem Peradilan Pidana Anak. Praktik Sistem Peradilan Pidana Anak telah memberikan jaminan perlindungan hukum terhadap hak-hak anak sebagai korban, yang meliputi mendapatkan rehabilitasi medis, Psikososial, restitusi, konseling dan segala bentuk perlindungan dan pendampingan pada setiap tingkat pemeriksaan mulai dari penyidikan, penuntutan sampai dengan pemeriksaan di sidang pengadilan (Manihuruk, \& Rochaeti, 2016).

Penyebab terjadinya kekerasan seksual pada anak, oleh Hikmah (2017) dapat digolongkan menjadi; pengaruh pornoaksi dan pornografi, rangsangan dari penampilan busana minim dan ketat, pergaulan dan lingkungan anak, dan lemahnya pengetahuan dan keterampilan melindungi diri bagi anak. Penyebab yang terakhir menjadi perhatian besar untuk ditindak-lanjuti. Bahwa memberikan pengetahuan dan keterampilan kepada anak menjadi upaya preventif dalam mengurangi angka kekerasan seksual pada anak (Harahap dkk, 2015)

Sekolah menjadi tempat potensial untuk memberikan pendidikan seksual agar anak terlindungi dari kekerasan seksual. Seperti peran konselor sekolah yang dapat dioptimalkan dalam menangani kekerasan seksual pada anak (Fathiyah, 2010). Upaya penanggulangan menjadi konsentrasi ketika telah terjadi kekerasan tetapi upaya preventif sebaiknya dilakukan lebih intensif. Peran konselor dapat dilakukan oleh guru jenjang sekolah dasar dimana anak-anak rentan mengalami kekerasan seksual. Pemberian pemahaman kepada anak sejak dini dari bahaya kekerasan seksual menjadi rekomendasi (Nisa, 2018; Fathiyah, 2010). Oleh karena itu, guru sekolah dasar harus memiliki kemampuan sebagai pengajar yang bertugas menyampaikan ilmu pengetahuan yang memberikan informasi 
kepada peserta didiknya (Hamalik, 2004).

Dalam rangka meningkatkan kompetensi guru dalam melaksanakan pendidikan perlindungan anak dari kekerasan seksual, guru memerlukan sumber belajar yang dapat dipelajari secara fleksibel. Sumber belajar bagi guru yang sesuai dengan kebutuhan tersebut dapat berupa modul yang memungkinkan guru dapat belajar secara mandiri.

Modul sering dijadikan media sosialisasi yang dapat diakses secara mandiri dan fleksibel. Selain dapat dipelajari secara mandiri, modul menjadi daya tarik bagi guru yang sedang mendalami suatu pembelajaran (Suparman, 2014) dan meningkatkan pemahaman dan keterampilan guru di sekolah (Astuti, Sugiyatno, \& Purwanti, 2015; Sugiarti, 2012).

\section{METODE}

\begin{tabular}{llr}
\multicolumn{1}{c}{ Metode } & penelitian ini & merupakan \\
penelitian & pengembangan. & Model \\
pengembangan & yang digunakan & dalam \\
penelitian ini & adalah model penelitian
\end{tabular} prosedural yang mengacu pada model desain instruksional milik Dick, Carey, \& Carey (2015). Pada umumnya, model ini memiliki sepuluh langkah: mengidentifikasi tujuan pembelajaran umum, melakukan analisis instruksional, menganalisis karakteristik awal pengguna dan konteks instruksional, merumuskan tujuan instruksional khusus, mengembangkan instrumen penilaian hasil belajar, mengembangkan strategi pembelajaran, mengembangkan bahan ajar, melakukan evaluasi formatif (melaksanakan uji produk), dan melakukan revisi.

Peneliti mengidentifikasi tujuan pembelajaran umum dengan cara melakukan analisis instruksional dan menganalisis karakteristik guru dan konteks sekolah melalui wawancara mendalam kepada guru di sekolah dasar yang tersebar di empat sekolah negeri di Kota Yogyakarta pada tahun 2018. Sebanyak 3 orang guru merupakan wanita dan seoarang guru adalah laki-laki. Kisaran usia guru berada pada 25-35 tahun. Hasil wawancara kepada para guru menghasilkan rekomendasi tujuan pembelajaran umum yang perlu dicapai guru setelah menggunakan modul pendidikan perlindungan anak dari kekerasan seksual.

Berdasarkan tujuan instruksional umum, peneliti merumuskan tujuan instruksional khusus melalui FGD (Forum Group Discussion) antar peneliti yang merupakan para ahli pembelajaran yang ada di jurusan Kurikulum dan Teknologi Pendidikan. Peneliti kemudian melakukan studi pustaka dari artikel dan buku referensi tentang upaya pencegahan kekerasan seksual pada anak untuk mensinergikan hasil FGD, sehingga dihasilkan tujuan pembelajaran khusus yang secara operasional dapat diamati. Hal ini sekaligus membantu peneliti merumuskan penilaian hasil belajar guru yang tercantum di dalam modul.

Peneliti mengembangkan strategi pembelajaran mandiri karena produk yang dikembangkan berupa modul pembelajaran untuk guru. Oleh karena itu, modul dikembangkan dengan memperhatikan prinsip desain dan karakteristik modul instruksional. Format modul yang dikembangkan berupa modul tercetak yang telah menempuh uji produk oleh ahli media dan ahli materi sebagai upaya mengevaluasi produk secara formatif. Hasil evaluasi tersebut menjadi bahan revisi modul menjadi lebih baik dan layak diuji cobakan kepada guru. Pada artikel ini akan dibahas tentang kelayakan modul yang dikembangkan dari hasil evaluasi para pakar dan tidak dijelaskan dengan detail hasil uji coba kepada guru sebagai pengguna akhir.

Data diperoleh melalui angket penilaian yang diisi oleh seorang ahli media dan seorang ahli materi, kemudian dianalisis dengan menggunakan analisis deskriptif kualitatif. Analisis ini dimaksudkan untuk menggambarkan karakteristik data pada masing-masing variabel penilaian. Dengan ini diharapkan akan mempermudah memahami data untuk proses analisis selanjutnya.

Data kuantitatif yang diperoleh melalui angket penilaian dianalisis dengan statistik desktiptif kemudian dikonversikan ke data kualitatif dengan skala 4 untuk mengetahui kelayakan modul instruksional tersebut. 
Tabel 1. Konversi Data Kuanitatif ke Data Kualitatif dengan Skala 4

\begin{tabular}{clll}
\hline $\begin{array}{c}\text { Data } \\
\text { Kuant } \\
\text { itatif }\end{array}$ & \multicolumn{2}{c}{ Rentang } & Data Kualitatif \\
\hline 4 & $\mathrm{X} \geq \mathrm{Xi}+1 . \mathrm{Sbi}$ & $\mathrm{X} \geq 3.00$ & Sangat Baik \\
3 & $\mathrm{Xi}+1 . \mathrm{Sbi}>\mathrm{X} \geq \mathrm{Xi}$ & $3.00>\mathrm{X} \geq 2.50$ & Baik \\
2 & $\mathrm{Xi}>\mathrm{X} \geq-1 . \mathrm{Sbi}$ & $2.50>\mathrm{X} \geq 2.00$ & Kurang \\
1 & $\mathrm{X} \geq \mathrm{Xi}+1 . \mathrm{Sbi}$ & $\mathrm{X}<2.00$ & Sangat Kurang \\
\hline
\end{tabular}

Dalam penelitian ini, kelayakan modul ditentukan dengan nilai minimal kategori baik (skor 3). Apabila hasil penilaian oleh ahli materi dan ahli media memberikan hasil akhir lebih dari atau sama dengan kategori 'baik', maka modul yang dikembangkan dinyatakan layak untuk diuji cobakan pada guru.

\section{HASIL DAN PEMBAHASAN}

\section{Hasil}

\section{Deskripsi Identifikasi Kebutuhan Instruksional}

Berdasarkan wawancara kepada para guru, riwayat kekerasan seksual pada anak (siswa di sekolah mereka) biasanya dilakukan oleh orang terdekat di sekitar rumah bahkan kerabat sendiri. Sebagian besar latar belakang keluarga siswa adalah keluarga yang berperangai keras dan kurang perhatian kepada anak. Anak yang menjadi korban tiba-tiba menjadi anak yang pendiam.

Pengetahuan guru yang diwawancarai mengenai konten pendidikan perlindungan anak dari kekerasan memang cukup beragam. Salah seorang guru yang diwawancarai mengungkapkan bahwa penyebab terjadinya kekerasan seksual pada anak disebabkan kurangnya perhatian orang tua kepada anak. Guru kedua menyatakan bahwa kekerasan dapat terjadi kepada anak karena anak dipekerjakan orang tua dengan minimal pendapatan yang harus dipenuhi saat mengemis. Anak yang dipekerjakan ini rentan terhadap kekerasan seksual.

Selama ini, upaya-upaya yang dilakukan pihak sekolah adalah melakukan penyuluhan kepada siswa tentang bagian-bagian tubuh yang tidak boleh disentuh oleh lawan jenis. Sekolah juga memberikan peringatan maupun teguran kepada siswa yang melakukan pelecehan seksual secara verbal maupun fisik kepada temannya. Pihak sekolah bekerja sama dengan orang tua untuk melakukan pengawasan perilaku anak.

Para guru yang diwawancarai dari berbagai bidang studi lebih menginginkan belajar pengetahuan baru (pendidikan perlindungan anak dari kekerasan seksual) melalui buku modul daripada mendengarkan rekaman ceramah maupun menggunakan multimedia pembelajaran berbasis komputer. Atas dasar ini, peneliti kemudian menggali sejauh mana modul pembelajaran yang diinginkan guru. Mereka menginginkan modul dengan materi yang praktis, menyajikan contoh kehidupan sehari-hari, dan mendorong latihan atau praktik.

Para pakar pembelajaran memberikan pendapat kepada peneliti tentang isu pendidikan perlindungan anak yang rentan kekerasan seksual agar setidaknya menambahkan tiga konten utama di dalam modul. Tiga tema yang dianjurkan tersebut anatara lain tentang konsep kekerasan seksual pada anak, kompetensi guru dalam pendidikan perlindungan anak, dan rancangan pembelajaran integratif perlindungan anak dari kekerasan seksual. Pada akhirnya, modul dibuat berdasarkan identifikasi tujuan instruksional yang menghasilkan tiga capaian pembelajaran: (1) guru mampu menjelaskan konsep dan jenis-jenis kekerasan seksual terhadap anak serta dasar-dasar perlindungannya, (2) guru mampu menjelaskan upaya-upaya perlindungan anak dari kekerasan seksual melalui kompetensi pedagogik guru, dan (3) guru mampu merancang pembelajaran yang mengintegrasikan upaya perlindungan anak dari kekerasan seksual.

\section{Penyusunan dan Pengembangan Modul}

Kegiatan ini berupa kegiatan menulis tujuan instruksional khusus, menyusun materi modul, menyusun kegiatan belajar, dan menyusun alat penilaian hasil belajar. Langkah penyusunan dan pengembangan modul dilakukan secara holistik dan menggunakan 
waktu yang cukup. Rancangan modul dalam tahap identifikasi instruksional menjadi pedoman dalam penulisan modul hingga menjadi protipe modul tercetak yang dapat dipakai secara bebas oleh guru.

Modul dengan 65 halaman ini terdiri dari tiga bab yang merupakan representasi dari tujuan instruksional umum yang telah dirumuskan. Pada setiap permulaan bab terdapat penjelasan tujuan pembelajaran khusus yang indikator ketercapaiannya diukur melalui soal-soal yang ada di akhir setiap bab modul. Peneliti tetap memberikan kisi-kisi jawaban dari soal-soal yang ada di modul agar guru dapat mengkonfirmasi jawaban secara mandiri. Berikut cuplikan modul pada bagian tujuan instruksional khusus, dalam hal ini peneliti menuliskannya sebagai sub capaian pembelajaran.

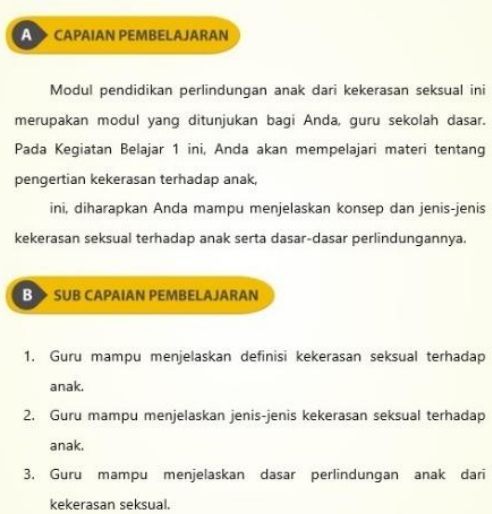

Gambar 1. Cuplikan tujuan instruksional modul

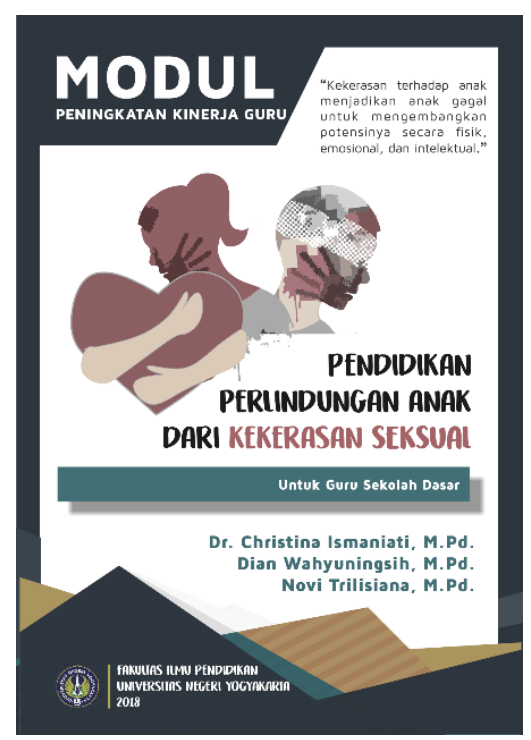

Gambar 2. Tampilan sampul modul

\section{Penilaian Ahli terhadap Modul}

Protipe modul kemudian dinilai oleh ahli materi dan ahli media. Ahli materi maupun ahli media dipilih berdasarkan kapasitas yang mumpuni. Pada tahap validasi ahli materi, diperoleh kesimpulan bahwa produk modul ini sangat layak dan dapat diuji coba lapangan pada penelitian selanjutnya.

Angket penilaian yang diisi oleh ahli materi terdiri dari 16 butir pernyataan yang menjadi indikator penilaian pengembangan modul dari segi materi. Berikut indikator penilaian aspek materi:

Tabel 2. Penilaian aspek materi

\begin{tabular}{|c|c|c|}
\hline No & Aspek penilaian ahli materi & $\begin{array}{c}\text { Rata-rata } \\
\text { penilaian } \\
\text { (Kategori) }\end{array}$ \\
\hline 1 & $\begin{array}{l}\text { Materi } \\
\text { a. kejelasan capaian pembelajaran } \\
\text { b. kesesuaian materi dengan capaian } \\
\text { pembelajaran } \\
\text { c. kesesuaian materi dengan } \\
\text { perkembangan zaman } \\
\text { d. kesesuaian materi dengan subjek } \\
\text { penelitian } \\
\text { e. kesesuaian ruang lingkup materi } \\
\text { f. kedalaman dan keluasan materi } \\
\text { g. keruntutan materi }\end{array}$ & $\begin{array}{c}3.00 \\
\text { (Sangat } \\
\text { Baik) }\end{array}$ \\
\hline 2 & $\begin{array}{l}\text { Pembelajaran } \\
\text { a. kesesuaian judul modul } \\
\text { b. kesesuaian metode penyampaian } \\
\quad \text { dalam modul } \\
\text { c. kejelasan rangkuman pada modul } \\
\text { d. kesesuaian evaluasi dalam modul } \\
\text { e. kejelasan pemberian contoh dalam } \\
\text { modul } \\
\text { f. kesesuaian daftar pustaka dalam } \\
\text { modul } \\
\text { g. ketepatan format penyajian materi } \\
\text { h. ketepatan umpan balik } \\
\text { i. ketepatan evaluasi berupa Latihan }\end{array}$ & $\begin{array}{c}3.11 \\
\text { (Sangat } \\
\text { Baik) }\end{array}$ \\
\hline
\end{tabular}

Adapun rerata skor penilaian ahli materi dari 16 butir tersebut adalah sebesar 3,06. Bila dikonversikan berdasarkan tabel konversi, maka hasil penilaian ahli materi secara keseluruhan adalah 'sangat baik'.

Selanjutnya adalah penilaian yang diisi oleh ahli media. Penilaian ahli media terdiri dari enam sub aspek dengan total 51 butir pernyataan yang menjadi indikator penilaian pengembangan modul dari segi media. Berikut tabel indikator penilaian ahli media secara singkat: 
Tabel 3. Penilaian aspek media

\begin{tabular}{clc}
\hline No & Aspek penilaian ahli media & $\begin{array}{c}\text { Rata-rata } \\
\text { penilaian } \\
\text { (Kategori) }\end{array}$ \\
\hline 1 & Bentuk fisik modul & $\begin{array}{c}4.00 \\
\text { (Sangat Baik) }\end{array}$ \\
\hline 2 & Sampul modul & $\begin{array}{c}4.00 \\
\text { (Sangat Baik) }\end{array}$ \\
\hline 3 & Kata pengantar dan daftar isi & $\begin{array}{c}4.00 \\
\text { (Sangat Baik) }\end{array}$ \\
\hline 5 & Uraian materi kegiatan belajar & $\begin{array}{c}3.71 \\
\text { (Sangat Baik) }\end{array}$ \\
\hline 6 & Latihan dan rambu-rambu jawaban & $\begin{array}{c}4.00 \\
\text { (Sangat Baik) }\end{array}$ \\
\hline
\end{tabular}

Rerata skor penilaian ahli media dari 51

butir tersebut adalah sebesar 3,88. Bila dikonversikan berdasarkan tabel konversi di atas, maka hasil penilaian ahli media secara keseluruhan adalah 'sangat baik'.

\section{Pembahasan}

Modul pendidikan perlindungan anak dari kekerasan seksual dinyatakan layak oleh para ahli yang kemudian direkomendasikan untuk uji coba kepada guru sebagai pengguna modul. Modul yang merupakan hasil pengembangan ini dapat dinyatakan layak setelah didesain dengan memperhatikan prinsip modul instruksional seperti; mencantumkan tujuan instruksional, menyajikan urutan materi ke dalam subbab yang ramping, mencantumkan ilustrasi dan contoh kontekstual, dan mendukung latihan. Hasil penilaian para ahli terhadap modul ini berdasarkan prinsip modul instruksional menjadi pendukung teori Suparman (2014) yaitu, modul seharusnya memungkinkan penggunanya belajar secara mandiri (self-instruction).

Keunggulan modul ini didukung oleh konten yang dirancang untuk memberikan pembelajaran yang self instruction, self contained, dan self explanatory. Modul ini dinilai oleh para ahli dapat membelajarkan guru secara mandiri dengan penjelasan yang jelas dan memadai karena salah satu alasannya adalah konten materi disusun berdasarkan urutan kegiatan belajar yang tepat, baik secara hirarki mapun prosedural.

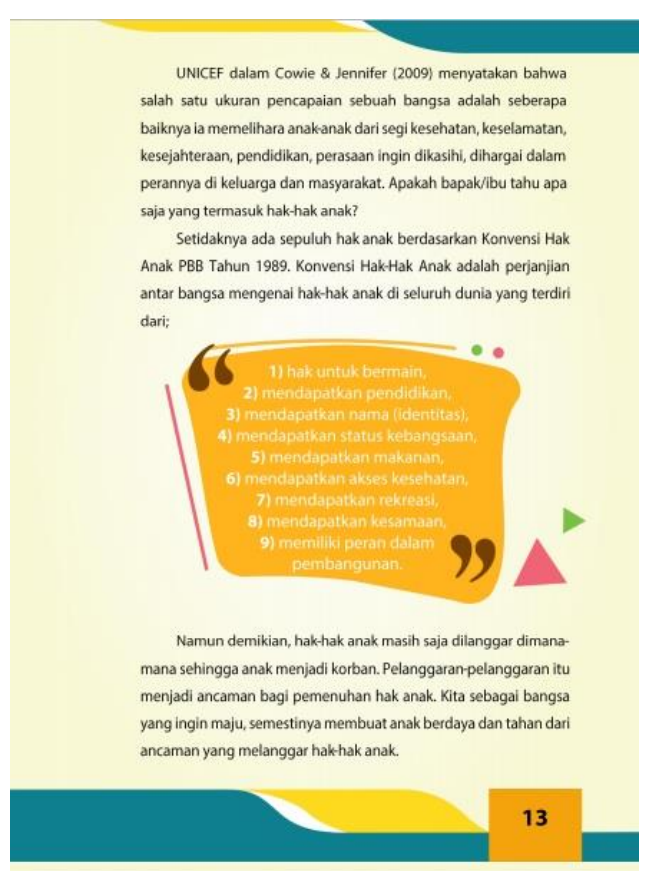

Gambar 3. Keruntutan konten modul

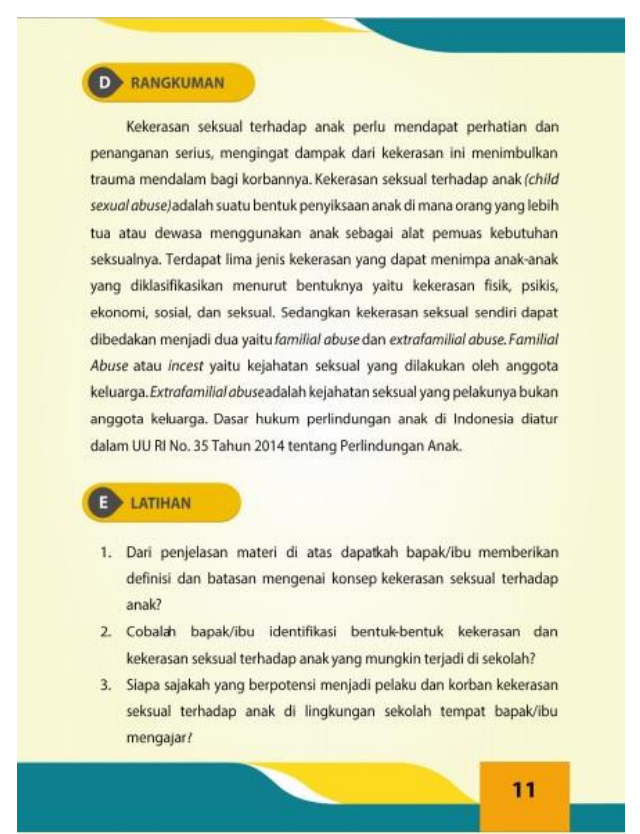

Gambar 4. Modul menyertakan rangkuman dan mendorong latihan

Tampilan modul dengan pemilihan jenis huruf maupun ukuran huruf disesuaikan dengan karakteristik orang dewasa. Pada umumnya, jenis huruf tidak berekor menjadi pilihan yang disukai orang dewasa dan warna huruf didominasi warna hitam dan biru. Warna dingin menjadi warna rujukan untuk oarang dewasa (Philips, 1997). Selain itu, tampilan modul telah memudahkan guru mengakses materi karena telah terdapat daftar isi, nomor halaman, kesesuaian judul materi dengan halaman. Oleh karena itu, tampilan 
modul memungkinkan guru melakukan selfcontained.

Modul ditinjau dari perolehan skor penilaian, secara keseluruhan berada pada kategori 'sangat baik' yang berarti modul ini layak dari aspek media dan materi. Perolehan nilai tersebut mengindikasikan bahwa pengembangan modul dilakukan sesuai prosedur yang baik. Urutan proses pengembangan dimulai dari mengidentifikasi capaian pembelajaran, menentukan garis besar materi, menuliskan berbagai konten materi dari berbagai sumber, hingga pada penentuan format dan tata letak agar sesuai dengan karakteristik guru sebagai pengguna.

Dari aspek media, modul ini menyajikan format media seperti teks, gambar, dan bagan yang memberikan pengalaman belajar yang self explanatory karena digunakan mengikuti prinsip desain pembelajaran (Budiningsih, 2008). Modul dikembangkan dan dinilai melalui instrumen penilaian yang telah diteliti dengan mempertimbangkan prinsip desain pesan pembelajaran. Jadi, modul ini telah lolos uji kelayakan dari segi desain pesan pembelajaran.

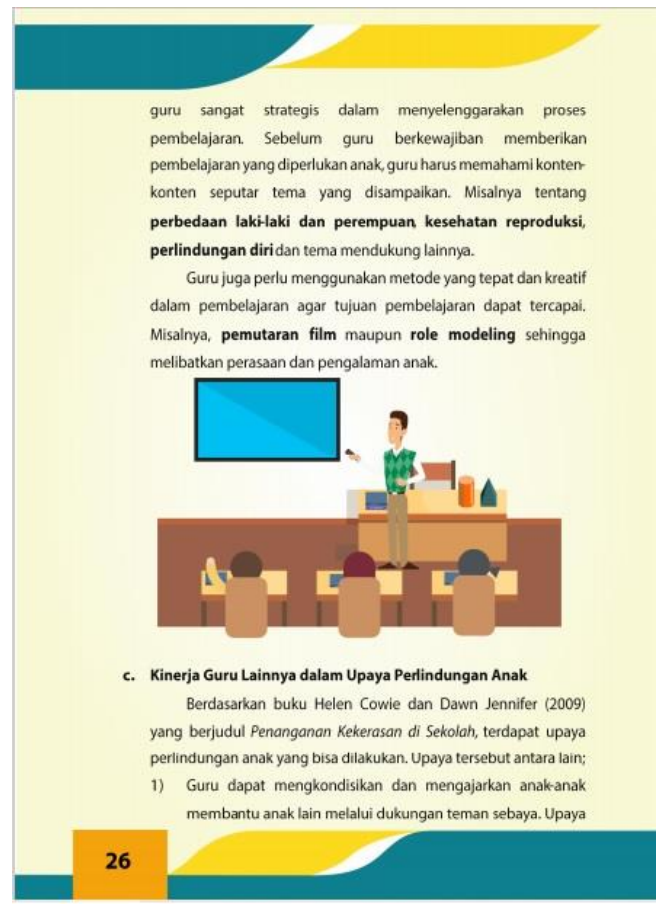

Gambar 5. Ilustrasi penjelas teks berpadu dengan seimbang

Dari aspek materi, konten materi yang ada di dalam modul disusun dari beragam sumber referensi yang selanjutnya dikemas sesuai dengan teori belajar kognitif dan konstruktivistik agar mampu mencapai tujuan pembelajaran secara optimal. Materi dikemas berdasarkan pemahaman struktur kognitif secara deduktif yaitu dimulai dari penyajian uraian/konsep, contoh dan latihan. Di akhir setiap bab terdapat rangkuman sebagai bentuk perulangan materi agar masuk ke dalam long term memory. Latihan dikemas berdasarkan teori konstruktivistik dimana guru perlu menjawab soal yang berpotensi menghasilkan jawaban yang kreatif dan subjektif.

\section{PENUTUP}

Produk modul pendidikan perlindungan anak dari kekerasan seksual yang dihasilkan berupa buku tercetak yang memiliki variasi warna; tampilan fisik; desain teks, gambar, dan bagan sesuai karakteristik guru sebagai pengguna modul. Modul yang dihasilkan telah sesuai dengan prosedur pengembangan berupa metode pengembangan prosedural dalam merancang instruksional.

Modul yang dihasilkan telah melewati uji validasi dari ahli materi dan ahli media berdasarkan instrumen yang tervalidasi pula. Hasil penilaian ahli media terhadap modul dikategorikan sebagai sangat baik. Hasil penilaian ahli materi terhadap modul dikategorikan sebagai sangat baik. Jadi, penilaian keseluruhan modul disimpulkan layak untuk diuji coba pada tahap pengguna modul (guru).

Modul pendidikan perlindungan anak dari kekerasan seksual disarankan untuk dimanfaatkan di sekolah-sekolah yang siswasiswanya rentan mengalami kekerasan. Rekomendasi pada penelitian selanjutnya adalah pengembangan modul dapat terintegrasi dengan format media digital seperti video maupun audio yang dapat diakses melalui internet, sehingga pengalaman belajar yang dihadirkan bervariasi dalam memfasilitasi guru secara optimal. 


\section{DAFTAR PUSTAKA}

Astuti, B., Sugiyatno, and Purwanti, I.Y., "Pengembangan Modul Pendidikan Karakter Berbasis Kearifan Lokal bagi Guru TK," Laporan Penelitian Pendidikan Karakter, LPPM UNY, 2015.

Budiningsih, A. "Desain Pesan Pembelajaran", FIP UNY, 2008.

Cowie, H. \& Jennifer, D., "Penanganan Kekerasan Di Sekolah: Pendekatan Lingkup Sekolah untuk Mencapai Praktik Terbaik," Terjemahan Ursula Gyani, SAGE Publications, 2009.

Dick, W., Carey, L., \& Carey, J.O., "The Systematic Design of Instruction Eight Edition," Pearson, 2015.

Efianingrum, A.,"Pengarusutamaan Hak Anak di Sekolah untuk Mencegah Kekerasan,"Fondasia 10 (2), 43-57 (2010).

Fathiyah, K.N., "Peran Konselor Sekolah untuk Penanganan Kekerasan Seksual pada Anak,"Paradigma 09 (5), 75-88 (2010).

Gani, M., "Perlindungan Anak Dari Kekerasan," Quantum Jurnal Ilmiah Kesejahteraan Sosial 18 (26), 134-140 (2018).

Hamalik, O., "Pendidikan Guru Berdasarkan Pendekatan Kompetensi," Bumi Aksara, 2004.

Harahap, F., Fathiyah, K.N., Izzaty, R.E., and Purwanti, I.Y., "Pengembangan Media Gambar sebagai Alat Edukasi untuk Meningkatkan Antisipasi Diri Anak Terhadap Perilaku Kekerasan," Laporan Penelitian Unggulan UNY, LPPM UNY, 2015.

Hikmah, S., "Mengantisipasi Kejahatan Seksual Terhadap Anak Melalui Pembelajaran "Aku Anak Berani Melindungi Diri Sendiri": Studi di Yayasan Al-Hikmah Grobogan". Sawwa 12 (2), 187-206 (2017).

Kinnear, K.L., "Childhood Sexual Abuse," ABC-CLIO Inc, 2007.

Manihuruk, T.N.S., \& Rochaeti, N., "Perlindungan Hak Anak Korban Phedofilia Dalam Sistem Peradilan
Pidana Anak (Studi Tentang Penanganan Kasus Kejahatan Seksual Terhadap Anak Di Polrestabes Semarang," Jurnal Law Reform 12 (1), 121- 131 (2016).

Nisa, I.K., "Pengembangan Modul Pendidikan Seks untuk Meningkatkan Pemahaman Siswa terhadap Bahaya Perilaku Seks Bebas di SMP Negeri 1 Pulosari Kabupaten Pemalang," Master. thesis, Program Studi Bimbingan dan Konseling, Universitas Negeri Yogyakarta, Yogyakarta, 2018.

Philips, R., "The Developers Handbooks to Interactive Multimedia: A Practical Guide for Educational Aplications", Kogan Page, 1997.

Sitanggang, F.L., \& Sumaryanto, P., "Upaya Guru Mencegah Perilaku Kejahatan Seksual Melalui Penerapan Pendidikan Seks pada Anak Usia Dini di PAUD Rajawali Ende Kecamatan Tanjung Priok Kelurahan Tanjung Priok," Bina Manfaat Ilmu Jurnal Pendidikan 2 (3), 148-160 (2018).

Sugiarti, Y., "Penyusunan Modul Pembelajaran Keterampilan Membaca Teks Bahasa Jerman bagi Guru-Guru Bahasa Jerman DIY dan Jateng," Laporan Penelitian dan Pengabdian Masyarakat, LPPM UNY, 2012.

Supardi, “Kinerja Guru”, Raja Grafindo, 2013.

Suparman, A., "Disain Instruksional Modern: Panduan Para Pengajar dan Inovator Pendidikan," Erlangga, 2014.

Suyanto, B., "Masalah Sosial Anak," Kencana, 2010. 